\title{
Haematology, genotoxicity, enzymatic activity and histopathology as biomarkers of metal pollution in the shrew Crocidura russula
}

\author{
A. Sánchez-Chardi a,b,*, C.C. Marques ${ }^{\text {c }}$, S.I. Gabriel ${ }^{\text {c }}$, F. Capela-Silva ${ }^{\text {d }}$, A.S. Cabrita ${ }^{\text {, }}$ \\ M.J. López-Fuster ${ }^{a}$, J. Nadal ${ }^{a}$, M.L. Mathias ${ }^{c}$ \\ a Departament Biologia Animal, Facultat de Biologia, Universitat Barcelona, Av. Diagonal 645, 08028 Barcelona, Spain \\ ${ }^{\mathrm{b}}$ Servei de Microscòpia, Facultat de Ciències, Ed. C, Universitat Autònoma de Barcelona, 08193 Bellaterra, Barcelona, Spain \\ ${ }^{c}$ Centro de Biologia Ambiental, Departamento de Biologia Animal, Faculdade de Ciências, Universidade de Lisboa, Campo Grande, 1749-016 Lisboa, Portugal \\ ${ }^{\mathrm{d}}$ Centro de Investigação em Ciências e Tecnologias da Saúde, Departamento de Biologia, Universidade de Évora, 7002-552 Évora, Portugal \\ ${ }^{\text {e } C e n t r o ~ d e ~ H i s t o f i s i o l o g i a, ~ I n s t i t u t o ~ d e ~ P a t o l o g i a ~ E x p e r i m e n t a l, ~ F a c u l d a d e ~ d e ~ M e d i c i n a, ~ U n i v e r s i d a d e ~ d e ~ C o i m b r a, ~ 3004-504 ~ C o i m b r a, ~ P o r t u g a l ~}$
}

Metals from an abandoned pyrite mine produce alterations in haematological parameters, GST, MNT, and histopathology in shrews.

\section{A R T I C L E I N F O}

\section{Article history:}

Received 10 July 2007

Received in revised form 28 December 2007

Accepted 29 February 2008

Available online $\mathrm{xxx}$

\section{Keywords:}

Crocidura russula

Biomarkers

Pollution

Pyrite mine

Histopathology

\begin{abstract}
A B S T R A C T
Haematological (WBC, RBC, Hgb and Hct) and genotoxicity (MNT) parameters, hepatic enzymatic activities (GST, GPx and GR), and a histopathological evaluation of liver, kidneys and gonads were assessed as general biomarkers of metal pollution in the shrew Crocidura russula inhabiting a pyrite mining area. Specimens exposed to metals presented a few significant alterations when compared with reference animals: GST activity decreased; micronuclei increased; and evident liver alterations related to metal exposure were observed. On the basis of all the parameters studied, age was an important factor that partly explained the observed variation, whereas sex was the least important factor. Significant correlations were also found between heavy metal concentrations and biomarkers evaluated, demonstrating the great influence of these metals in the metabolic alterations. To the best of our knowledge, these data constitute the first measurements of a battery of biomarkers in shrews from a mine site and are among the few available for insectivorous mammals.
\end{abstract}

(ㄷ) 2008 Elsevier Ltd. All rights reserved.

\section{Introduction}

Abandoned mines constitute a serious environmental problem throughout the world. These sites represent a potential threat to human and ecosystems health and cause important impacts on wide areas over long periods if nothing is done toward pollution mitigation. The mine of Aljustrel is a good example of this situation. This mine site is one of the biggest deactivated pyrite mines in Portugal and spills out great amounts of liquid effluents, in what is known as acid mine drainage (AMD), characterized by high metal contents and low $\mathrm{pH}$. In terrestrial food webs, toxic levels of some metals are easily reached in abandoned mining sites due to the high bioavailability of metals found in these areas. In fact, previous studies have reported the accumulation of several metals in soils, plants, and animals as well as their physiological effects in areas affected by deactivated mines in this country (e.g. Gerhardt et al.,

\footnotetext{
* Corresponding author. Servei de Microscòpia, Facultat de Ciències, Ed. C, Campus de la Universitat Autònoma de Barcelona, 08193 Bellaterra, Barcelona, Spain. Tel.: +34 935811516; fax: +34 935812090

E-mail address: Alejandro.Sanchez.Chardi@uab.es (A. Sánchez-Chardi).
}

2005; Pereira et al., 2006; Quevauviller et al., 1989; Sánchez-Chardi et al., 2007b). In spite of this high risk, scarce data are available concerning the influence of metal pollution on the health of species belonging to higher trophic levels, such as shrews. Almost no data were found on the effects of contamination in carnivorous small mammals inhabiting abandoned pyrite mining areas, Marques et al. (2007) quantify few haematological and enzymatic parameters in greater white-toothed shrews, Crocidura russula, from a $\mathrm{Pb} / \mathrm{Zn}$ mine site. To our knowledge, the present study measures, for the first time, a battery of biomarkers in C. russula.

The assessment of physiological effects of chronic exposure to metals using biomarkers of sublethal toxicity is necessary in order to evaluate the impact of pollution under realistic conditions. These effects include genotoxic (Ieradi et al., 1996; Sánchez-Chardi and Nadal, 2007), enzymatic (Lopes et al., 2002; ŚwiergoszKowalewska et al., 2006), haematological (Nunes et al., 2001; Reynolds et al., 2006; Rogival et al., 2006), and histological alterations (Clark et al., 1992; Damek-Poprawa and Sawicka-Kapusta, 2004; Pereira et al., 2006; Stansley and Roscoe, 1996) that in general only occur when substantial concentrations of metals are present in the tissues. In fact, the combined use of biomarkers with bioaccumulation data provides a suitable measure of health status, 
physiological condition, and response of terrestrial small mammal populations to pollution (e.g. Świergosz et al., 1998; Walker, 1998).

Environmental control should be multidirectional, but one of the most essential criteria of analysis is related to observations carried out on wild animals. Small mammals are ideal for monitoring environmental pollution as well as for evaluating the risk for human populations living in polluted areas such as abandoned metalliferous mining sites (e.g. Pereira et al., 2006; Sánchez-Chardi et al., 2007b; Talmage and Walton, 1991; Walker, 1998).

Here we quantify haematological and genotoxic parameters, enzymatic activities, and histopathological alterations in shrews inhabiting an abandoned pyrite mining site. Moreover, the effect of age and sex was also measured and correlations between metal bioaccumulation and biomarkers were determined in order to explain the variation found in these parameters. Finally, with all this information in mind, we discuss the risk involved with this kind of environmental pollution and the suitability of insectivorous mammals as bioindicators.

\section{Material and methods}

2.1. Study sites

This study was carried out in the vicinity of the deactivated pyrite mine of Aljustrel, located in the Baixo Alentejo province (southern Portugal). Deactivated about a decade ago, approximately 50,000,000 t of target metals were extracted from this mine during its 130 years of exploitation. The sampled area in Aljustrel $\left(37^{\circ} 53^{\prime} 08^{\prime \prime} \mathrm{N} ; 08^{\circ} 08^{\prime} 32^{\prime \prime} \mathrm{W}\right)$ is located along the "Água forte" riverside, where the stored acidic effluents are discharged during rainy periods. For comparative purposes, an area with similar relief, climate and vegetation, located $69 \mathrm{~km}$ northeast of the Aljustrel mine $\left(38^{\circ} 11^{\prime} 13^{\prime \prime} \mathrm{N} ; 07^{\circ} 24^{\prime} 34^{\prime \prime} \mathrm{W}\right)$ was selected as a reference, considering that no exogenous sources of heavy metals are known. The climate of the region where both sampling areas are located is characterized by hot dry summers and mild winters. The vegetation mainly consists of sparsely scattered specimens of Quercus rotundifolia, as well as several shrub and herbaceous species (Rubus ulmifolius, Nerium oleander, Echium plantagineum, Bromus rigidus, Vulpia myuros, and Phleum phleoides).

In 2003, a total of 34 specimens of the greater white-toothed shrew were livetrapped using Longworth ${ }^{\circledR}$ and Sherman ${ }^{\circledR}$ traps. Hepatic metal concentrations of these shrews were reported in a previous study (see Table 1). Distribution of captures by site, sex, and age is showed in Table 2 . All captured animals appeared to be in good physical condition with no major signs of illness or deformity. Animals were sexed, weighed and transported to the laboratory. After a slight anaesthesia, specimens were sacrificed by cervical dislocation in strict accordance with ethical directives on the protection of animals.

\subsection{Haematological and genotoxic parameters}

Peripheral blood was collected by cardiac punction using heparinized syringes. White blood cells count (WBC, $\times 10^{3} \mathrm{~mm}^{-3}$ ), red blood cells count (RBC, $\times 10^{6} \mathrm{~mm}^{-3}$ ), haemoglobin concentration $\left(\mathrm{Hgb}, \mathrm{g} \mathrm{dl}^{-1}\right)$, and haematocrit (Hct, \%) were quantified in a Coulter Counter Analyser (Beckman Coulter, USA).

For the micronucleus test, duplicate blood smears were made for each specimen on pre-cleaned microscope slides, fixed with heat, and stained with conventional May-Grünwald-Giemsa stain. For each individual, micronucleus (MN) frequency

\section{Table 1}

Mean \pm SEM values for metals in liver of $C$. russula from the reference and the Aljustrel mine site (in $\mu \mathrm{g} \mathrm{g}^{-1}$ dry weight)

\begin{tabular}{lcc}
\hline & Reference site $(n=22)$ & Mine site $(n=31)$ \\
\hline $\mathrm{Fe}$ & $1257.36 \pm 160.03$ & $2958.45 \pm 395.21^{* * *}$ \\
$\mathrm{Mg}$ & $899.81 \pm 27.51$ & $987.32 \pm 83.84$ \\
$\mathrm{Zn}$ & $145.23 \pm 7.27$ & $167.26 \pm 19.18$ \\
$\mathrm{~Pb}$ & $0.77 \pm 0.09$ & $5.26 \pm 0.75^{* * *}$ \\
$\mathrm{Cu}$ & $23.83 \pm 10.31$ & $28.31 \pm 16.17$ \\
$\mathrm{Mn}$ & $17.56 \pm 0.74$ & $17.26 \pm 1.42$ \\
$\mathrm{Hg}$ & $0.26 \pm 0.05$ & $1.03 \pm 0.26^{* * *}$ \\
$\mathrm{Cd}$ & $2.27 \pm 0.65$ & $8.61 \pm 1.47^{* * *}$ \\
$\mathrm{Mo}$ & $3.38 \pm 0.24$ & $5.30 \pm 0.52^{* *}$ \\
$\mathrm{Cr}$ & $1.32 \pm 0.11$ & $1.12 \pm 0.28^{* *}$ \\
$\mathrm{Ni}$ & $0.67 \pm 0.24$ & $1.48 \pm 0.17^{* * *}$ \\
\hline
\end{tabular}

${ }^{*} p \leq 0.05 ;{ }^{* *} p \leq 0.01 ;{ }^{* * *} p \leq 0.001$.

After Sánchez-Chardi et al. (2007b).
Table 2

Distribution of specimens by site, sex and age

\begin{tabular}{llllr}
\hline Site & Sex & Age & & Total \\
\cline { 3 - 4 } & & Juveniles & Adults & \\
\hline Reference & Males & 6 & 4 & 10 \\
\multirow{2}{*}{ Mine } & Females & 5 & 3 & 8 \\
& Males & 4 & 4 & 8 \\
& Females & 4 & 4 & 8 \\
\hline
\end{tabular}

was scored on 2000 blood erythrocytes through an oil immersion objective $(\times 100)$ on a Leica Leitz DMRB microscope.

\subsection{Enzymatic parameters}

A liver portion of about $300 \mathrm{mg}$ was rinsed in an ice-cold $0.154 \mathrm{mM} \mathrm{KCl}$ solution immediately after dissection. Glutathione S-transferase (GST), glutathione peroxidase (GPx) and glutathione reductase (GR) activities were assessed according to Habig et al. (1974), Paglia and Valentine (1967) and Carlberg and Mannervik (1985), respectively. Total protein contents were determined according to the Biuret method (Gornall et al., 1949) using Bovine Serum Albumin (Sigma, Spain) as standard. Additional methodological descriptions may be found in Marques et al. (2007).

\subsection{Histopathological evaluation}

A small part of the liver, the right kidney and the gonads were fixed in $10 \%$ neutral-buffered formalin, dehydrated in ethanol, cleared in xylene and embedded in paraffin wax. Sections of $5 \mu \mathrm{m}$ thick were stained with conventional hematoxylin and eosin and the slides were examined by light microscopy. The incidence of alterations was reported in a qualitative evaluation. Moreover, for statistical purposes the severity of alterations was measured on a semi-quantitative scale scored in four categories according to the intensity of alterations: without alteration (0), slightly altered (1), intermediately altered (2), and strongly altered (3).

\subsection{Statistical analyses}

All data were expressed as mean \pm standard error $(M \pm S E M)$. When necessary data were log transformed and then tested for normal distribution (Shapiro-Wilk test) and homogeneity of variance (Levene, F-test). Comparisons of haematological and enzymatic parameters by age, sex, and site were performed with Student's tests $(t)$. Significant genotoxic and histopathological divergences for these three factors were assessed using Mann-Whitney tests $(U)$. Moreover, for each of these factors data were pooled in order to obtain an appropriate sample size for statistical analyses. To investigate associations between bioaccumulation and its effects, Spearman or Pearson correlation coefficients $(r)$ were calculated between hepatic metal concentrations and enzymatic, haematological, histopathological, and genotoxic parameters for both study sites. All statistical analyses were performed with SPSS 11.5 software for Windows.

\section{Results}

\subsection{Haematological and genotoxic parameters}

Descriptive statistics for haematological parameters are shown in Table 3. Though no significant differences were found by study site, season, age, or sex in these parameters, a tendency toward increase was detected in specimens from the polluted site. An agedependent increase in both studied sites was also observed (Table $3)$. Moreover, at the polluted site, significant correlations were observed between RBC and $\mathrm{Pb}(r=-0.609, p=0.009), \mathrm{RBC}$ and $\mathrm{Cr}$ $(r=0.618, p=0.008)$, Hct and $\mathrm{Pb}(r=-0.510, p=0.036)$, and $\mathrm{Hgb}$ and $\mathrm{Cu}(r=0.525, p=0.031)$.

Shrews collected on the polluted site exhibited significantly higher micronuclei mean frequencies than specimens from the reference site $(1.00 \pm 0.15$ vs $0.14 \pm 0.09 \%$, respectively; $U=4.195$, $p=0.001$ ). No relationships were found in MN frequencies with age or sex; whereas significant correlations were detected between MN and several metals, namely $\mathrm{Fe}(r=0.722, p=0.002), \mathrm{Mn}$ $(r=-0.592, p=0.020), \mathrm{Cu}(r=-0.565, p=0.028), \mathrm{Pb}(r=0.524$ $p=0.045), \mathrm{Cd}(r=0.537, p=0.022)$, and $\mathrm{Cr}(r=-0.744, p=0.001)$. 
Table 3

Haematological parameters in C. russula by age and site

\begin{tabular}{|c|c|c|c|c|c|c|}
\hline & \multicolumn{3}{|l|}{ Reference site } & \multicolumn{3}{|l|}{ Mine site } \\
\hline & Juveniles $(n=8)$ & Adults $(n=8)$ & Total $(n=16)$ & Juveniles $(n=5)$ & Adults $(n=10)$ & Total $(n=15)$ \\
\hline $\mathrm{WBC}\left(\times 10^{3} \mathrm{~mm}^{-3}\right)$ & $3.150 \pm 0.327$ & $4.625 \pm 0.740$ & $3.887 \pm 0.435$ & $3.840 \pm 0.819$ & $4.060 \pm 0.749$ & $3.987 \pm 0.553$ \\
\hline $\mathrm{RBC}\left(\times 10^{6} \mathrm{~mm}^{-3}\right)$ & $5.997 \pm 0.917$ & $8.147 \pm 0.664$ & $7.072 \pm 0.613$ & $7.507 \pm 0.468$ & $8.544 \pm 0.526$ & $7.853 \pm 0.371$ \\
\hline $\operatorname{Hgb}\left(\mathrm{g} \mathrm{dl}^{-1}\right)$ & $12.212 \pm 0.861$ & $13.887 \pm 0.487$ & $13.050 \pm 0.524$ & $13.300 \pm 0.595$ & $14.130 \pm 0.427$ & $13.853 \pm 0.350$ \\
\hline Hct (\%) & $25.012 \pm 3.816$ & $34.700 \pm 2.887$ & $29.856 \pm 2.628$ & $34.920 \pm 1.970$ & $33.330 \pm 2.226$ & $33.860 \pm 1.592$ \\
\hline
\end{tabular}

\subsection{Enzymatic parameters}

Specimens from the abandoned mine site showed a significant decrease in GST activity $(t=-3.422 ; p=0.002)$. No site variation was found in the activity of the other quantified enzymes (Table 4). With age, a general tendency toward a decrease in GST activity was detected, while GPx (Reference site: $t=-2.336, p=0.034$ ) and GR tended to increase (Table 4). No sex-dependent variation was observed in enzymatic activities of $C$. russula from both study sites. Moreover, in the specimens from the polluted area, significant positive correlations were identified between GPx activity and hepatic concentrations of $\mathrm{Pb}(r=-0.587, p=0.013), \mathrm{Cu}(r=0.791$, $p<0.001)$, $\mathrm{Mn}(r=0.651, p=0.005)$, and $\mathrm{Cr}(r=0.536, p=0.027)$.

\subsection{Histopathological evaluation}

Specimens exposed to metal pollution in the mining area showed a significant increase in number and severity of pathological alterations, namely foci of cell necrosis, apoptosis, and cytoplasmic vacuolization in the hepatic tissue, when compared with reference shrews $(U=17.500 ; p<0.001$ ). In fact, $86 \%$ of the analysed specimens from the mine site showed evidences of necrosis and $79 \%$ of vacuolization. On the other hand, $8 \%$ of the specimens from the reference site showed evidences of necrosis and $58 \%$ presented signs of vacuolization. Moreover, a specimen from the polluted site showed evidences of apoptosis in the hepatic tissue with nuclei fragmentation and pyknotic nuclei. This was confirmed with an immunohistochemistry analysis, namely the detection of cysteine protease Caspase 3 (data not shown). Table 5 reports a semi-quantitative severity scale of alterations in the liver and Fig. 1 shows examples of control and altered tissues. No significant age- or sex-dependent variations were detected in these pathologies for either of the studied sites. There were also no significant relationships between pathologies and hepatic metal concentrations. Moreover, no alterations related with metal pollution were observed in the kidneys, testes or ovaries of any of the analysed shrews.

\section{Discussion}

Several pyrite mines have been closed in southern Portugal in the past few decades, mainly due to economic reasons. Most of them were abandoned without any previous environmental recovery plan, and thus have continued to be an environmental threat long after mining activities have ceased. Harmful effects to biota include deep changes in cells, tissues, individuals, populations, and ecosystems. However, scarce information is available on effects on higher trophic level species such as insectivorous mammals.

\subsection{Haematological and genotoxic parameters}

Registered values for haematological parameters are in agreement with available literature on small mammal species (see revision in Table 6). No significant differences were found between study sites in spite of the higher mean values detected in the polluted area. Such a result could, at least partially, be due to the great dispersion of data that may mask any significant difference. In fact, homeostasis of mammalian systems under chronic exposure to environmental pollution may decrease and/or attenuate differences in wild populations, in contrast with laboratory animals that often showed significant differences when acutely exposed to metals (e.g. Jadhav et al., 2007; Medina et al., 2007; Włostowski et al., 2003). Several studies have reported alterations of haematological parameters in Algerian mice, Mus spretus, house mice, Mus musculus, wood mice, Apodemus sylvaticus, and northern pocket gophers, Thomomys talpoides, inhabiting polluted sites (see Table 6). In our study, this tendency toward an increase of haematological values might be related with protective effects of essential metals such as iron or with interactions of toxic metals with oxygen transport, as suggested by the low level of efficiency of their mitochondria in the elimination of reactive oxygen species (ROS) and/or immunotoxic effects of pollutants (e.g. Tersago et al., 2004; Stewart et al., 2005). Moreover, the higher levels of toxic metals in adults as compared with juveniles and the alterations of metabolism in old animals could explain the tendency toward an increase of some haematological parameters with age. In accordance with our results, no sex-dependent variation was showed for the same analysed parameters in M. spretus and A. sylvaticus (Nunes et al., 2001; Rogival et al., 2006).

The micronuclei frequencies obtained for the reference area are in agreement with previously published data of background levels in C. russula and other small mammal species collected from different reference sites (see references in Sánchez-Chardi and Nadal, 2007). The significant positive correlation found between MN frequencies and non-essential metal concentrations in shrews from the pyrite mining site may be indicative of clastogenic effects of these elements in wild specimens (e.g. Ieradi et al., 1996; SánchezChardi and Nadal, 2007; Topashka-Ancheva et al., 2003; TullSingleton et al., 1994). Correlations between MN and essential elements could be partly explained by the protective and/or antagonistic effects between elements in specimens exposed to high concentrations of toxic metals.

Table 4

Enzymes activities ( $\mu \mathrm{mol} / \mathrm{min} / \mathrm{g}$ protein) in the liver of $C$. russula by age and site

\begin{tabular}{|c|c|c|c|c|c|c|}
\hline & \multicolumn{3}{|l|}{ Reference site } & \multicolumn{3}{|l|}{ Mine site } \\
\hline & Juveniles $(n=8)$ & Adults $(n=9)$ & Total $(n=17)$ & Juveniles $(n=6)$ & Adults $(n=11)$ & Total $(n=17)$ \\
\hline$\overline{\text { GST }}$ & $1094.01 \pm 96.99$ & $891.44 \pm 67.65$ & $986.76 \pm 61.54$ & $791.57 \pm 74.71$ & $628.36 \pm 89.37$ & $685.96 \pm 65.01$ \\
\hline GPx & $113.20 \pm 19.93$ & $161.57 \pm 11.34$ & $139.24 \pm 12.63$ & $128.55 \pm 10.45$ & $143.25 \pm 16.60$ & $133.14 \pm 8.73$ \\
\hline GR & $66.25 \pm 3.61$ & $68.11 \pm 3.12$ & $67.24 \pm 2.31$ & $64.67 \pm 4.24$ & $76.00 \pm 5.67$ & $71.75 \pm 4.04$ \\
\hline
\end{tabular}




\section{Table 5}

Frequency and intensity of histological alterations in livers of $C$. russula (without alteration $(-)$, slightly altered $(+)$, intermediately altered $(++)$, strongly altered $(+++))$

\begin{tabular}{|c|c|c|c|c|c|c|c|c|}
\hline & \multicolumn{4}{|c|}{ Reference site $(n=12)$} & \multicolumn{4}{|c|}{ Mine site $(n=14)$} \\
\hline & - & + & ++ & +++ & - & + & ++ & +++ \\
\hline Necrosis and degeneration & 11 & 1 & 0 & 0 & 2 & 8 & 4 & 0 \\
\hline Apoptosis & 12 & 0 & 0 & 0 & 13 & 0 & 0 & 1 \\
\hline Vacuolization & 5 & 4 & 2 & 1 & 3 & 1 & 4 & 6 \\
\hline
\end{tabular}

\subsection{Enzymatic parameters}

It is well documented that heavy metal exposure alters the normal activity of antioxidant enzymes, as reported in laboratory and wild mammals (e.g. Li et al., 2006; Lopes et al., 2002; Pinheiro et al., 2001; Reynolds et al., 2006; Viegas-Crespo et al., 2003). However, data with measurements on these parameters are quite scarce for shrews (Hamers et al., 2006; Marques et al., 2007). Some shrew species are among the smallest mammals and in order to maintain their body temperature, they have extremely high food requirements due to their high metabolic rate, which is higher than predicted by allometric scaling (e.g. Stewart et al., 2005). These atypical physiological conditions also affect enzyme activities in detoxification systems, as reported for the short-tailed shrew, Blarina brevicauda (Stewart et al., 2005). In the present study, though no significant differences were found for GPX and GR between study areas, a decrease of GST activity was registered in shrews from Aljustrel. GST catalyzes the conjugation of various substances with glutathione, playing an important role against oxidative stress. This result agrees with data provided by Świergosz-Kowalewska et al. (2006) for bank voles, Clethrionomys glareolus, exposed to metals from a zinc-lead smelter. Similar levels of $\mathrm{Cd}$ and $\mathrm{Pb}$ bioaccumulation in renal tissue (maximum $47 \mu \mathrm{g} \mathrm{g}^{-1}$ and $20 \mathrm{~g} \mathrm{~g} \mathrm{~g}^{-1}$, respectively) were reported in shrews from the Aljustrel mining site (Sánchez-Chardi et al., 2007b). In general, the nonsignificant differences detected in GPx and GR activities between
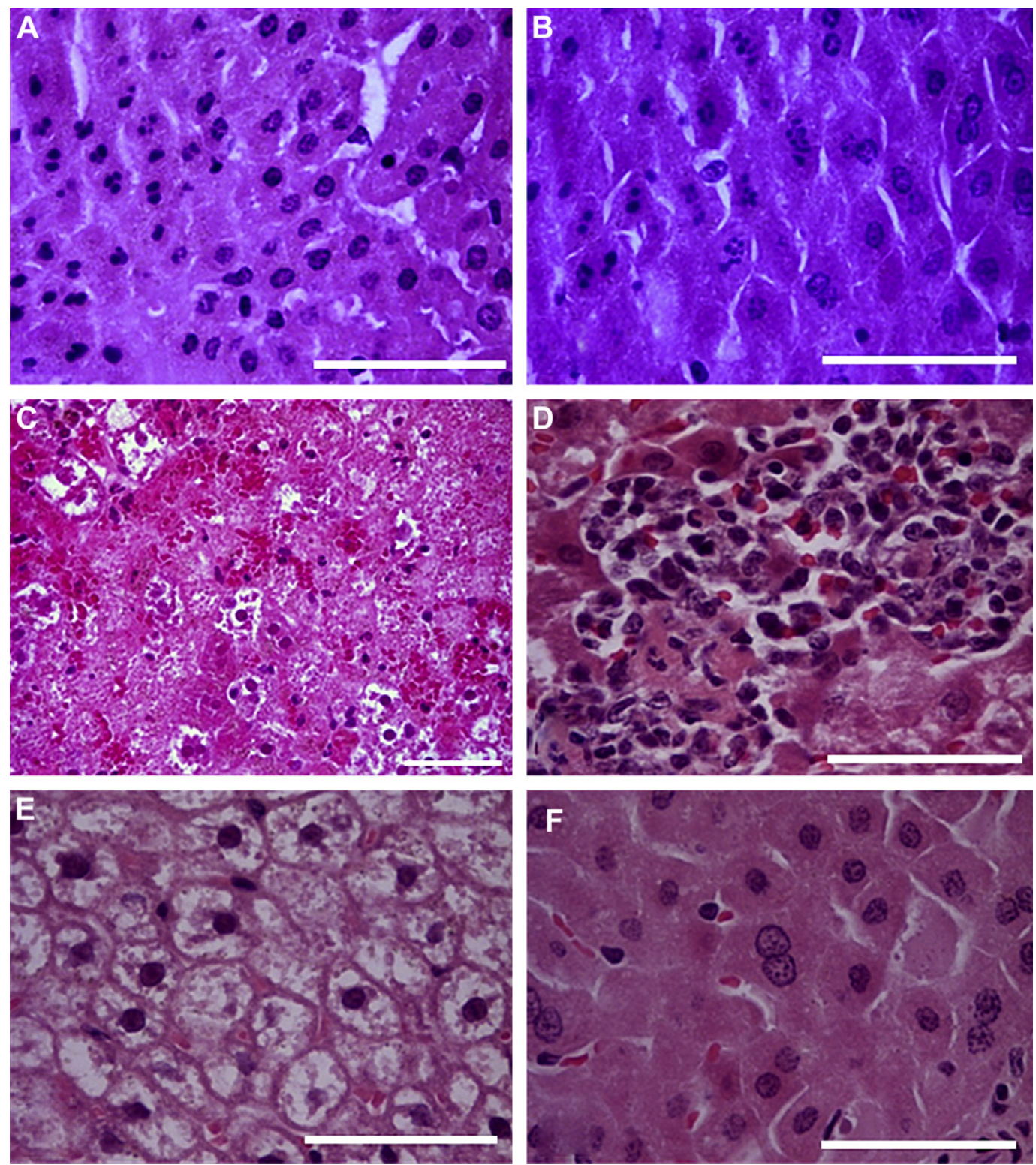

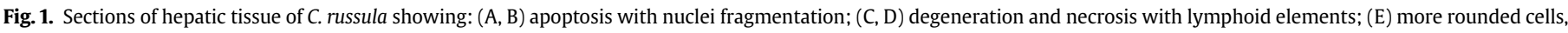
swollen parenchyma with vacuolization; and (F) normal hepatic tissue (bar size corresponding to $50 \mu \mathrm{m}$ ).

Please cite this article in press as: Sánchez-Chardi, A. et al., Haematology, genotoxicity, enzymatic activity and histopathology as biomarkers of metal pollution in the shrew Crocidura russula, Environ. Pollut. (2008), doi:10.1016/j.envpol.2008.02.026 
Table 6

Haematological parameters and hepatic enzymes activities (mean, mean $\pm \mathrm{SD}$, mean $\pm \mathrm{SEM}$ or mean and range) reported for wild small mammals from polluted (P) and reference ( $\mathrm{R}$ ) sites

\begin{tabular}{|c|c|c|c|c|c|c|c|c|c|c|c|c|}
\hline \multirow[t]{2}{*}{ Species } & & \multirow[t]{2}{*}{$n$} & \multicolumn{4}{|c|}{ Haematological parameters } & \multicolumn{4}{|c|}{ Enzymes activities } & \multirow{2}{*}{$\begin{array}{l}\text { Descriptive } \\
\text { statistics }\end{array}$} & \multirow[t]{2}{*}{ References } \\
\hline & & & $\begin{array}{l}\text { WBC } \\
\left(\times 10^{3} \mathrm{~mm}^{-3}\right)\end{array}$ & $\begin{array}{l}\text { RBC } \\
\left(\times 10^{6} \mathrm{~mm}^{-3}\right)\end{array}$ & $\mathrm{Hgb}\left(\mathrm{gl}^{-1}\right)$ & Hct (\%) & GST & GPx & GR & Units & & \\
\hline \multirow[t]{3}{*}{ Crocidura russula } & $\mathrm{P}$ & 16 & 4.80 & 8.13 & 14.0 & 35.7 & 1.18 & 0.128 & 0.067 & $\begin{array}{l}\mu \mathrm{M} / \mathrm{mg} \\
\text { prot/min }\end{array}$ & $\begin{array}{l}\text { Median } \\
\text { (range) }\end{array}$ & Marques et al. (2007) \\
\hline & $\mathrm{R}$ & 17 & 3.30 & 6.64 & 13.2 & 29.3 & 0.933 & 0.168 & 0.067 & & & \\
\hline & $\mathrm{R}$ & 6 & & $10.8 \pm 0.5$ & $15.6 \pm 1.7$ & $44.3 \pm 3.0$ & & & & & $M \pm \mathrm{SD}$ & Bartels et al. (1979) \\
\hline Suncus etruscus & $\mathrm{R}$ & 3 & & $18.3 \pm 0.3$ & $17.4 \pm 0.8$ & $50.3 \pm 1.5$ & & & & & & \\
\hline \multirow[t]{7}{*}{ Apodemus sylvaticus } & $\mathrm{P}$ & 25 & $1.42 \pm 2.25$ & $8.20 \pm 1.66$ & $16.00 \pm 1.53$ & $45.83 \pm 3.24$ & & & & & $M \pm S D$ & Gorriz et al. (1996) \\
\hline & $\mathrm{P}$ & 30 & $1.21 \pm 1.43$ & $8.43 \pm 1.42$ & $16.59 \pm 1.59$ & $47.40 \pm 4.43$ & & & & & & \\
\hline & $\mathrm{R}$ & 27 & $1.51 \pm 1.36$ & $8.57 \pm 1.78$ & $16.69 \pm 1.61$ & $46.77 \pm 4.06$ & & & & & & \\
\hline & $\mathrm{R}$ & $10-5$ & & & & & $\begin{array}{l}96.8 \pm 31.1- \\
89.2 \pm 32.7\end{array}$ & & & $\begin{array}{l}\mu \mathrm{M} / \mathrm{g} \text { WW } \\
\text { liver/min }\end{array}$ & $M \pm \mathrm{SD}$ & Lopes et al. (2002) \\
\hline & $\mathrm{P}$ & 6 & $1.34 \pm 0.15$ & $7.10 \pm 0.05$ & & & & & & & $M \pm \mathrm{SEM}$ & Tersago et al. (2004) \\
\hline & $\mathrm{P}$ & $7-8$ & $1.56 \pm 0.23$ & $8.92 \pm 0.03$ & & & & & & & & \\
\hline & $\mathrm{R}$ & 7-9 & $2.03 \pm 0.24$ & $8.94 \pm 0.04$ & & & & & & & & \\
\hline \multirow[t]{2}{*}{ Apodemus flavicollis } & $\mathrm{P}$ & 8 & $3.68 \pm 1.26$ & $8.16 \pm 0.88$ & $18.44 \pm 0.79$ & $54.4 \pm 4.08$ & & & & & $M \pm \mathrm{SEM}$ & $\begin{array}{l}\text { Topashka-Ancheva } \\
\text { et al. (2003) }\end{array}$ \\
\hline & $\mathrm{P}$ & 12 & $3.17 \pm 1.33$ & $7.8 \pm 3.2$ & $18.40 \pm 1.8$ & $56.2 \pm 2.7$ & & & & & & \\
\hline \multirow[t]{6}{*}{$\begin{array}{l}\text { Clethrionomys } \\
\text { glareolus }\end{array}$} & $\mathrm{P}$ & 6 & & & & & $0.921 \pm 0.292$ & $21.622 \pm 6.950$ & $0.053 \pm 0.009$ & $\begin{array}{l}\mu \mathrm{M} / \mathrm{mg} \\
\text { prot } / \mathrm{min}\end{array}$ & $M \pm \mathrm{SEM}$ & $\begin{array}{l}\text { Świergosz-Kowalewska } \\
\text { et al. (2006) }\end{array}$ \\
\hline & $\mathrm{P}$ & 5 & & & & & $0.334 \pm 0.057$ & $5.642 \pm 1.017$ & $0.134 \pm 0.016$ & & & \\
\hline & $\mathrm{R}$ & 10 & & & & & $0.558 \pm 0.113$ & $27.134 \pm 9.124$ & $0.196 \pm 0.042$ & & & \\
\hline & $\mathrm{P}$ & 9 & $3.73 \pm 8.58$ & $8.25 \pm 1.00$ & $17.82 \pm 1.8$ & $53.92 \pm 3.39$ & & & & & $M \pm \mathrm{SEM}$ & $\begin{array}{l}\text { Topashka-Ancheva } \\
\text { et al. (2003) }\end{array}$ \\
\hline & $\mathrm{P}$ & 8 & $3.15 \pm 1.25$ & & $17.80 \pm 1.0$ & $54 \pm 0.8$ & & & & & & \\
\hline & $\mathrm{R}$ & 11 & $2.83 \pm 0.75$ & $9.97 \pm 1.56$ & $20.30 \pm 1.3$ & $55.31 \pm 4.75$ & & & & & & \\
\hline \multirow[t]{2}{*}{ Chionomys nivalis } & $\mathrm{P}$ & 5 & $3.62 \pm 1.16$ & $8.92 \pm 1.81$ & $14.8 \pm 2.34$ & $49.95 \pm 4.87$ & & & & & $M \pm \mathrm{SEM}$ & $\begin{array}{l}\text { Topashka-Ancheva } \\
\text { et al. (2003) }\end{array}$ \\
\hline & $\mathrm{R}$ & 4 & & $10.96 \pm 1.36$ & $16.85 \pm 2.1$ & $46.15 \pm 3.43$ & & & & & & \\
\hline \multirow[t]{5}{*}{$\begin{array}{l}\text { Microtus } \\
\quad \text { pennsylvanicus }\end{array}$} & $\mathrm{P}$ & 23 & $4.4 \pm 0.5$ & & & & & & & & $M \pm \mathrm{SEM}$ & $\begin{array}{l}\text { Knopper and Mineau } \\
\text { (2004) }\end{array}$ \\
\hline & $\mathrm{P}$ & 27 & $5.2 \pm 0.6$ & & & & & & & & & \\
\hline & $\mathrm{P}$ & 5 & $4.6 \pm 1.1$ & & & & & & & & & \\
\hline & $\mathrm{P}$ & 11 & $4.5 \pm 0.5$ & & & & & & & & & \\
\hline & $\mathrm{R}$ & 10 & $5.2 \pm 0.6$ & & & & & & & & & \\
\hline \multirow[t]{5}{*}{ Mus spretus } & $\mathrm{P}$ & $60-80$ & $7.92 \pm 5.81$ & $8.23 \pm 1.57$ & $15.6 \pm 2.6$ & $37.7 \pm 7.9$ & & & & & $M \pm \mathrm{SD}$ & Nunes et al. (2001) \\
\hline & $\mathrm{R}$ & $36-46$ & $6.83 \pm 4.35$ & $8.49 \pm 0.84$ & $15.1 \pm 1.7$ & $39.1 \pm 4.6$ & & & & & & \\
\hline & $\mathrm{R}$ & $16-14$ & & & & & $\begin{array}{l}162.8 \pm 93.8- \\
129.5 \pm 37.1\end{array}$ & & & $\begin{array}{l}\mu \mathrm{M} / \mathrm{g} \text { WW } \\
\text { liver/min }\end{array}$ & $M \pm \mathrm{SD}$ & Lopes et al. (2002) \\
\hline & $\mathrm{P}$ & 49 & & & & & $187.8 \pm 56.9$ & & & $\begin{array}{l}\mu \mathrm{M} / \mathrm{g} \mathrm{WW} \\
\text { liver/min }\end{array}$ & $M \pm \mathrm{SD}$ & $\begin{array}{l}\text { Viegas-Crespo et al. } \\
(2003)\end{array}$ \\
\hline & $\mathrm{R}$ & 30 & & & & & $147.3 \pm 73.9$ & & & & & \\
\hline \multirow[t]{2}{*}{ Peromyscus leucopus } & $\mathrm{P}$ & 11 & & & $14.0(11.5-16.0)$ & $47(37-55)$ & & & & & $\begin{array}{l}\text { Mean } \\
\text { (range) }\end{array}$ & $\begin{array}{l}\text { Stansley and Roscoe } \\
\text { (1996) }\end{array}$ \\
\hline & $\mathrm{R}$ & 12 & & & $15.0(12.5-17.0)$ & $49(42-56)$ & & & & & & \\
\hline \multirow{4}{*}{$\begin{array}{l}\text { Peromyscus } \\
\text { maniculatus }\end{array}$} & $\mathrm{P}$ & 19 & & & 14.6 & 44.3 & & & & & $M$ & Kucera (1988) \\
\hline & $\mathrm{P}$ & 34 & & & 15.2 & 48.5 & & & & & & \\
\hline & $\mathrm{R}$ & 44 & & & 12.4 & 40.7 & & & & & & \\
\hline & $\mathrm{R}$ & 44 & & & 12.7 & 41.4 & & & & & & \\
\hline \multirow[t]{3}{*}{ Thomomys talpoides } & $\mathrm{P}$ & 10 & $2.71 \pm 0.44$ & & & & & & & & $M \pm \mathrm{SEM}$ & Reynolds et al. (2006) \\
\hline & $\mathrm{P}$ & 9 & $5.29 \pm 1.17$ & & & & & & & & & \\
\hline & $\mathrm{R}$ & 10 & $4.81 \pm 0.78$ & & & & & & & & & \\
\hline
\end{tabular}


study sites can possibly be related to an adaptation or increasing tolerance of specimens to chronic metal exposure.

The free radical theory proposed by Harman (1992) postulates an increase of ROS with age and, therefore, a consequent increase of antioxidant defences. Moreover, age-dependent variations were reported in antioxidant activity of rats (e.g. Gupta et al., 1991) and in the activity of hepatic cytochrome P450 in common shrews, Sorex araneus (Hamers et al., 2006). Since toxic metals such as $\mathrm{Cd}, \mathrm{Pb}$, and $\mathrm{Hg}$ reached significantly higher levels in adult shrews as compared with juveniles collected in Aljustrel (Sánchez-Chardi et al., 2007b), the correlation found between enzyme activities and age might be indicative of metal toxicity when a certain level of bioaccumulation is reached, as well as a decline in cellular response to oxidative stress with increasing age (e.g. Holbrook and Ikeyama, 2002). In fact, several studies have showed that metal exposure can cause alterations of GPx, GST, and GR activities, preventing some adverse effects of oxidative stress induced by the production of ROS species (e.g. Cnubben et al., 2001; Jadhav et al., 2007; Li et al., 2006; ViegasCrespo et al., 2003).

In rodents (Fouchécourt and Rivière, 1995; Li et al., 2006) and insectivores (Hamers et al., 2006) sex-dependent variation has been previously reported in enzymes from detoxification systems. Nonetheless, no differences were found in C. russula in the present study, in agreement with other surveys using wild populations of small mammals (Lopes et al., 2002; Viegas-Crespo et al., 2003). These divergent results may be indicative of inter-species and/or inter-populations differences. Due to the scarce information available on biotic parameters obtained from wild populations of small mammals exposed to metal contamination, it is essential that more studies dealing with these aspects be carried out.

\subsection{Histopathological evaluation}

One of the goals of this study was to assess, for the first time, histological alterations related to metal exposure in livers of wild shrews. As far as we know, available data on the histopathological effects of metal pollution in wild insectivorous mammals are very scarce and limited to renal lesions (e.g. Stansley and Roscoe, 1996). Histopathological evaluation of target tissues is a suitable biomarker that provides important qualitative and quantitative information about acute or chronic effects of toxic compounds, sometimes not so finely predicted by other parameters (e.g. Reynolds et al., 2006; Jadhav et al., 2007; Thijssen et al., 2007). This approach is commonly used on laboratory animals but seldom on wild populations of insectivorous mammals. Several other studies have used the liver as the main target organ for the assessment of histopathological alterations, examining various rodent species exposed to non-essential metals on polluted sites (Clark et al., 1992; Damek-Poprawa and Sawicka-Kapusta, 2004; Pereira et al., 2006).

In the present study, shrews from the mining area presented an increase in the number and severity of pathological alterations in the liver attributed to the effects of bioaccumulation of toxic compounds in this organ. In fact, the relative liver weight increases and the hepatic levels of $\mathrm{Pb}, \mathrm{Hg}$, and $\mathrm{Cd}$ in these specimens were above the no-observed-adverse-effects-level (NOAEL) and, therefore, susceptible to toxic effects (Sánchez-Chardi et al., 2007a,b). Among tissues and cellular alterations, chronic exposure to these elements induces hepatic cell necrosis and apoptosis, and produces cytoplasmic vacuolization in hepatocytes, showing metal toxicity and carcinogenicity (e.g. Świergosz et al., 1998; Damek-Poprawa and Sawicka-Kapusta, 2004; Jadhav et al., 2007). However, it was impossible to determine which metal caused which specific lesion due to wild populations are often exposed to a mixture of toxics. These signs of hepatic damage may be due to oxygen deficiency and/or the presence of ROS induced by metal exposure. This can often occur when detoxifying systems such as metallothioneins are not responding efficiently enough to bind all metal ions (Świergosz et al., 1998; Włostowski et al., 2003; Jadhav et al., 2007).

Despite the abundance of data relating toxic effects with age and gender, no dependent variation was found in C. russula for the two parameters. The absence of histological changes in the kidneys, testes or ovaries of any of the analysed shrews may reflect these tissues higher tolerance to heavy metals. This physiological adaptation to chronic exposure is probably connected with efficient detoxification systems acting in these tissues or low exposure to toxic species of metals due to the important role of the liver in detoxification of xenobiotics uptaken in food.

\subsection{Small mammals as bioindicators}

Small mammals are often considered to represent an intermediate stage between low and high trophic levels, since they constitute important items in the diet of carnivorous birds and mammals. However, shrews are insectivorous and can be considered predators with a high position in the food-chain. In fact, they usually accumulate larger amounts of toxic pollutants than rodents, which makes these insectivores suitable bioindicators of environmental contamination (e.g. Talmage and Walton, 1991).

Wild mammals from polluted environments can uptake metals until toxic levels are reached. The assessment of this potential risk can be measured by daily intake, metal bioaccumulation in tissues, or through biomarkers that report toxic effects at different levels. Daily metal intake in shrews from the pyrite mine of Aljustrel remains unknown, but considering the high concentrations of non-essential metals found in tissues of the analysed specimens (Sánchez-Chardi et al., 2007b) it is obvious that it exceeds the threshold of toxicity. Even though biomarkers can be influenced by a multiplicity of factors under wild conditions, they provide suitable information on animals' health status when exposed to some sort of pollution in their natural habitat. In fact, the assessment of environmental pollution effects in wild biota has been a vital challenge for ecotoxicologists in spite of evident difficulties caused by constantly changing environments and high intra-specific variability.

Organelles, cells, tissues, organs, individuals, populations, communities, or ecosystems can suffer the deleterious consequences of toxic substances. An important and complicated issue is to understand precisely how pollutants affect each of these organizational levels. Here we have quantified several parameters in order to better understand possible deleterious effects of nonessential metal exposure from the sub-cellular to the individual and population levels. As a result, we reported significant genotoxic, enzymatic and histological alterations, as well as a tendency toward an increase in haematological parameters in shrews chronically exposed to metals in an abandoned mining area.

Several authors have suggested that wild small mammals inhabiting polluted sites are more sensitive than animals that are the subjects of laboratory experiments (e.g. Reynolds et al., 2006). Laboratory animals are usually under strict, controlled conditions, with minimal variation in abiotic (temperature, humidity, photoperiod, etc.) and biotic factors (such as gender or age). In addition, controlled contamination protocols usually involve animals uniformly exposed to a single toxic compound at a known and constant concentration. Conversely, specimens from natural populations live under numerous (and often uncontrolled) circumstances, such as parasitosis or reduced food availability, that can contribute to a decline in their health status. Thus the amount of energy available for essential activities and defence against toxic effects of metal exposure is considerably diminished. Moreover, in the wild, metal exposure frequently includes a combination of potentially toxic compounds that are not distributed constantly in 
time and space. These factors can lead to intra-specific variation, differential exposure and response (Talmage and Walton, 1991), contributing to the great variability observed in some parameters in polluted areas (e.g. Sánchez-Chardi et al., 2007a; Marques et al., 2007). Pollutants may also be transformed before exposure, producing cumulative effects and/or undergoing interactions between them. So wild populations chronically exposed to pollution apparently make use of adaptive processes to better tolerate toxicants in a changing environment (e.g. Marques et al., 2007; Medina et al., 2007). All these factors can complicate the interpretation of ecotoxicological data as some parameters often do not show statistical significance, but only increasing/decreasing tendencies. A multidirectional approach such as the one described in the present study is extremely important for a wider and more accurate view of the effects of environmental pollution.

\section{Conclusions}

Shrews from the abandoned pyrite mine of Aljustrel not only showed significant heavy metals accumulation in their tissues (above toxic levels) but also presented physiological alterations. Age was a factor that particularly contributed to the observed variability, whereas sex was the one that contributed the least to the variation of the quantified parameters. Statistically significant correlations were reported between biomarkers and heavy metal contents. In spite of these relationships, none of the analysed metals can be pointed to as being chiefly responsible for the variation of the quantified biomarkers. A number of other metals, as well as other xenobiotics often present in wild conditions, may have also contributed to these results.

The combination of multiple biomarkers at different levels of organization can contribute to an integrative view of overall effects of environmental pollution at realistic conditions in wild specimens and populations. Here we have showed that non-destructive biomarkers such as MNT and haematological parameters provide suitable information, but histopathological evaluation of target tissues has revealed itself to be an important, specific, and sensitive tool for ecotoxicological assessment.

\section{Acknowledgements}

This study was supported by the Generalitat de Catalunya (2005SGR00602), the Spanish Ministerio de Educación y Ciencia (ACI/2004HP-00026) and the Portuguese Fundação para a Ciência e a Tecnologia (POCTI/39917/BSE/2001), cofinanced by FEDER funds. ASC received a BE grant from the Generalitat de Catalunya (2002BEAI00182), whereas CCM was supported by a PhD fellowship (FCT/SFRH/BD/5018/2001). We thank Prof. W.J. Manning and two anonymous reviewers for their helpful comments and suggestions on an earlier draft of the manuscript.

\section{References}

Bartels, H., Bartels, R., Baumann, R., Fons, R., Jurgens, K.D., Wright, P., 1979. Blood oxygen transport and organ weights of two shrew species (S. etruscus and $C$. russula). American Journal of Physiology 236, 221-224.

Carlberg, I., Mannervik, B., 1985. Glutathione reductase. Methods in Enzymology 113, 484-491.

Clark Jr., D.R., Foerster, K.S., Marn, C.M., Hothem, R.L., 1992. Uptake and environmental contaminants by small mammals in pickleweed habitats at San Francisco Bay, California. Archives of Environmental Contamination and Toxicology 22, 389-396.

Cnubben, N.H.P., Rietjens, I.M.C.M., Wortelboer, H., van Zanden, J., van Bladeren, P.J., 2001. The interplay of glutathione-related processes in antioxidant defense. Environmental Toxicology and Pharmacology 10, 141-152.

Damek-Poprawa, M., Sawicka-Kapusta, K., 2004. Histopathological changes in the liver, kidneys, and testes of bank voles environmentally exposed to heavy metal emissions from the steelworks and zinc smelter in Poland. Environmental Research 96, 72-78.
Fouchécourt, M.O., Rivière, J.L., 1995. Activities of cytochrome P450-dependent monooxygenases and antioxidant enzymes in different organs of Norway rats (Rattus norvegicus) inhabiting reference and contaminated sites. Chemosphere 31, 4375-4386.

Gerhardt, A., de Bisthoven, J., Soares, A.M.V.M., 2005. Effects of acid mine drainage and acidity on the activity of Choroterpes picteti (Ephemeroptera: Leptophlebiidae). Archives of Environmental Contamination and Toxicology 48, 450458.

Gornall, A.G., Bardawill, C.J., David, M.M., 1949. Determination of serum proteins by means of the biuret reaction. Journal of Biological Chemistry 177, 751-766.

Gorriz, A., Llacuna, S., Riera, M., Nadal, J., 1996. Effects of air pollution on hematological and plasma parameters in Apodemus sylvaticus and Mus musculus. Archives of Environmental Contamination and Toxicology 31, 153-158.

Gupta, A.M., Hasan, R., Chander, R., Kapoor, N.K., 1991. Age related elevation of lipid peroxidation products: diminution of superoxide dismutase activity in the central nervous system of rats. Gerontology 37, 305-309.

Habig, W.H., Pabst, M.J., Jacoby, W.B., 1974. Glutathione S-transferases. The first enzymatic step in mercapturic acid formation. Journal of Biological Chemistry 249, 7130-7139.

Hamers, T., van den Berg, J.H.J., van Gestel, C.A.M., van Schooten, F.J., Murk, A.J., 2006. Risk assessment of metals and organic pollutants for herbivorous and carnivorous small mammal food chains in a polluted floodplain (Biesbosch, The Netherlands). Environmental Pollution 144, 581-595.

Harman, D., 1992. Free radical theory of aging. Mutation Research 275, 257-266.

Holbrook, N.J., Ikeyama, S., 2002. Age-related decline in cellular response to oxidative stress: links to growth factor signalling pathways with common defects. Biochemical Pharmacology 64, 999-1005.

Ieradi, L.A., Cristaldi, M., Mascanzoni, D., Cardarelli, E., Grossi, R., Campanella, L., 1996. Genetic damage in urban mice exposed to traffic pollution. Environmental Pollution 92, 323-328.

Jadhav, S.H., Sarkar, S.N., Aggarwal, M., Tripathi, H.C., 2007. Induction of oxidative stress in erythrocytes of male rats subchronically exposed to a mixture of eight metals found as groundwater contaminants in different parts of India. Archives of Environmental Contamination and Toxicology 52, 145-151.

Knopper, L.D., Mineau, P., 2004. Organismal effects of pesticide exposure on meadow voles (Microtus pennsylvanicus) living in golf course ecosystems: developmental instability, clinical haematology, body condition, and blood parasitology. Environmental Toxicology and Chemistry 23, 1512-1519.

Kucera, E., 1988. Effect of smelter emissions on the hemogram of the deer mouse (Peromyscus maniculatus). Environmental Pollution 55, 173-177.

Li, G., Sang, N., Guo, D., 2006. Oxidative damage induced in hearts, kidneys and spleens of mice by landfill leachate. Chemosphere 65, 1058-1063.

Lopes, P.A., Viegas-Crespo, A.M., Nunes, A.C., Pinheiro, T., Marques, C., Santos, M.C., Mathias, M.L., 2002. Influence of age, sex, and sexual activity on trace element levels and antioxidant enzyme activities in field mice (Apodemus sylvaticus and Mus spretus). Biological Trace Element Research 85 (3), 227-239.

Marques, C.C., Sánchez-Chardi, A., Gabriel, S.I., Nadal, J., Viegas-Crespo, A.M., Mathias, M.L., 2007. How does the greater white-toothed shrew, Crocidura russula, responds to long term heavy metal contamination? A case study. Science of the Total Environment 376, 128-133.

Medina, M.H., Correa, J.A., Barata, C., 2007. Micro-evolution due to pollution: Possible consequences for ecosystem responses to toxic stress. Chemosphere 67, 2105-2114.

Nunes, A.C., Mathias, M.L., Crespo, A.M., 2001. Morphological and haematological parameters in the Algerian mouse (Mus spretus) inhabiting an area contaminated with heavy metals. Environmental Pollution 113, 87-93.

Paglia, D.E., Valentine, W.N., 1967. Studies on the quantitative and qualitative characterization of erythrocyte glutathione peroxidase. Journal of Laboratory and Clinical Medicine 70, 158-169.

Pereira, R., Pereira, M.L., Ribeiro, R., Gonçalves, F., 2006. Tissues and hair residues and histopathology in wild rats (Rattus rattus L.) and Algerian mice (Mus spretus Lataste) from an abandoned mine area (Southeast Portugal). Environmental Pollution 139, 561-575.

Pinheiro, T., Rocha, P., Lopes, P.A., Viegas-Crespo, A.M., Santos, M.C., Mathias, M.L., 2001. Laboratory testing of biochemical effects of $\mathrm{Mn}$, Fe and Se in the Algerian mouse (Mus spretus). Ecotoxicology and Environmental Restoration 4, 60-63.

Quevauviller, P., Lavigne, R., Cortez, L., 1989. Impact of industrial and mine drainage wastes on the heavy metal distribution in the drainage basin and estuary of the Sado river (Portugal). Environmental Pollution 59, 267-286.

Reynolds, K.D., Schwarz, M.S., McFarland, C.A., McBride, T., Adair, B., Strauss, R.E., Cobb, G.P., Hooper, M.J., McMurry, S.T., 2006. Northern pocket gophers (Thomomys talpoides) as biomonitors of environmental metal contamination. Environmental Toxicology and Chemistry 25, 458-469.

Rogival, D., Scheirs, J., De Coen, W., Verhagen, R., Blust, R., 2006. Metal blood levels and hematological characteristics in wood mice (Apodemus sylvaticus L.) along a metal pollution gradient. Environmental Toxicology and Chemistry 25, 149-157.

Sánchez-Chardi, A., Nadal, J., 2007. Bioaccumulation of metals and effects of a landfill in small mammals. Part I. The greater white-toothed shrew, Crocidura russula. Chemosphere 68, 703-711.

Sánchez-Chardi, A., López-Fuster, M.J., Nadal, J., 2007a. Bioaccumulation of lead, mercury, and cadmium in the greater white-toothed shrew, Crocidura russula, from the Ebro Delta (NE Spain): sex- and age-dependent variation. Environmental Pollution 145, 7-14.

Sánchez-Chardi, A., Marques, C.C., Nadal, J., Mathias, M.L., 2007b. Metal bioaccumulation in the greater white-toothed shrew, Crocidura russula, inhabiting an abandoned pyrite mine site. Chemosphere 67, 121-130. 
Stansley, W., Roscoe, D.E., 1996. The uptake and effects of lead in small mammals and frogs at a trap and skeet range. Archives of Environmental Contamination and Toxicology 30, 220-226.

Stewart, J.M., Woods, A.K., Blakely, J.A., 2005. Maximal enzyme activities, and myoglobin and glutathione concentrations in heart, liver and skeletal muscle of the Northern short-tailed shrew (Blarina brevicauda; Insectivora: Soricidae). Comparative Biochemistry and Physiology B 141, 267-273.

Świergosz, R., Zakrzewska, M., Sawicka-Kapusta, K., Bacia, K., Janowska, I., 1998. Accumulation of cadmium in and its effect on bank vole tissues after chronic exposure. Ecotoxicology and Environmental Safety 41, 130-136.

Swiergosz-Kowalewska, R., Bednarska, A., Kafel, A., 2006. Glutathione levels and enzyme activity in the tissues of bank vole Clethrionomys glareolus chronically exposed to a mixture of metal contaminants. Chemosphere 65, 963-974.

Talmage, S.S., Walton, B.T., 1991. Small mammals as monitors of environmental contaminants. Reviews of Environmental Contamination and Toxicology 119, 47-145.

Tersago, K., De Coen, W., Scheirs, J., Vermeulen, K., Blust, R., Van Bockstaele, D. Verhagen, R., 2004. Immunotoxicology in wood mice along a heavy metal pollution gradient. Environmental Pollution 132, 385-394.

Thijssen, S., Maringwa, J., Faes, C., Lambrichts, I., Van Kerklove, E., 2007. Chronic exposure of mice to environmentally relevant, low doses of cadmium leads to early renal damage, not predicted by blood or urine cadmium levels. Toxicology 229, 145-156

Topashka-Ancheva, M., Metcheva, R., Teodorova, S., 2003. A comparative analysis of the heavy metal loading of small mammals in different regions of Bulgaria. II: chromosomal aberrations and blood pathology. Ecotoxicology and Environmental Safety 54, 188-193.

Tull-Singleton, S., Kimball, S., McBee, K., 1994. Correlative analysis of heavy meta bioconcentration and genetic damage in white-footed mice (Peromyscus leucopus) from a hazardous waste site. Bulletin of Environmental Contamination and Toxicology 52, 667-672.

Viegas-Crespo, A.M., Lopes, P.A., Pinheiro, M.T., Santos, M.C., Rodrigues, P.D. Nunes, A.C., Marques, C., Mathias, M.L., 2003. Hepatic elemental contents and antioxidant enzyme activities in Algerian mice (Mus spretus) inhabiting a mine area at Central Portugal. Science of the Total Environment 311, 101-109.

Walker, C.H., 1998. Biomarker strategies to evaluate the environmental effects of chemicals. Environmental Health Perspectives 106, 613-620.

Włostowski, T, Krasowska, A., Bonda, E., 2003. An iron-rich diet protects the live and kidneys against cadmium-induced injury in the bank vole (Clethrionomys glareolus). Ecotoxicology and Environmental Safety 54, 194-198. 